\title{
Oriental studies education in Russia. Training of Mongolists at the beginning of the 20th century to 1920 .
}

\author{
Oksana N. Polyanskaya ${ }^{1, *}$, Ivan N. Semushev ${ }^{1, * *}$. \\ ${ }^{1}$ Banzarov Buryat State University, 670000, 6, Ranzhurova st., Ulan-Ude, Russia
}

\begin{abstract}
The article is devoted one of the most difficult periods in the history of Russian and Soviet Oriental studies, including Mongolian studies - the transition from the science of the Russian Empire to the Soviet one. At this time there was a change in the entire system of scientific knowledge. The Orientalist institutions of the scientific and educational plan were faced with tasks radically different from the prerevolutionary ones. It was necessary to take a step away from the study of sources, language issues, ancient periods of the peoples of the East. In exchange for this refusal, a transition was made to the study of living Oriental languages and issues of socio-economic importance in line with the new Soviet methodology. The article, in contrast to Soviet historiography, argues for the point of view on the development of practical Mongolian studies in pre-revolutionary Russia, which had considerable experience in the program and institutions for the training of Mongolian practitioners. The main inspirer of practical Oriental studies was the Mongol scholar A.M. Pozdneev. He was the first director of the Oriental Institute in Vladivostok, and rector of the Practical Academy at the Society of Oriental Studies in St. Petersburg - educational institutions. There he trained future specialists in the modern East. Soviet Oriental institutes adopted this experience, adapting it to new conditions. In this regard, there was a reorganization of the Lazarev Institute in Moscow. On its basis, with a significant expansion of the curriculum programs, the Central Institute of Living Oriental Languages was established. And in St. Petersburg, using the experience of the Academy at the Society of Oriental Studies, the work of the Petrograd (Leningrad) organized the Institute of Living Oriental Languages.
\end{abstract}

\section{Introduction}

The beginning of the $\mathrm{XX}$ century is known for the further development of Oriental science in Russia and education. This development was concentrated in the educational centers of the country - universities and institutes. By the beginning of the 20th century, Russian Orientalism had created such sections of orientalism as Caucasian studies, Mongolian studies, and Turkology. The works of domestic indologists and sinologists have been marked by significant successes. Most of the outstanding Orientalists worked as teachers at St. Petersburg University, and in subsequent periods became active organizers of new educational institutions of Orientalism. [1, 155].

The beginning of the XX century was difficult for the Mongol studies direction at St. Petersburg University. Due to the tense political situation in the Far East, there was a need to train military specialists with knowledge of Oriental languages: Mongolian, Chinese, Japanese. One of the leading teachers of the Faculty of Oriental Languages of the University Alexey Matveevich Pozdneev (1851-1920) was sent to Vladivostok. There he headed a higher educational institution of practical orientation - the Oriental Institute. The Oriental Institute was intended for the training of orientalists-practitioners who know the "living" Oriental languages and the modern East. In 1899, Professor K. F. Golstunsky, a teacher of many Mongolian scholars who would continue both teaching and scientific work at the university, died. One of them - Vladislav Ludvigovich Kotvich (1872-1944) could not fully devote himself to scientific and pedagogical activity, which began in 1895, because at that time he served in the Ministry of Finance. And Andrey Dmitrievich Rudnev (1878-1958) - the future researcher of the dialects of the Mongolian languages at that time had not yet graduated from university. Because of this, the teaching of the Mongolian language and the history of the Mongols was not taught at the faculty. It resumed only in 1901, when V.L. Kotvich moved to the university as a private professor to teach Mongolian literature [2]. Despite all the difficulties, St. Petersburg University continued to be the flagship of Oriental studies in Russia.

\section{Results}

Mongol studies, having survived the "personnel famine" of the turn of the XIX-XX centuries, confidently entered a new period of development. Already in the first decade of the XX century, a new group of Mongolologists began to work actively in St. Petersburg, and on the periphery, represented by bright names: A.M. Pozdneev, V.L. Kotvich, A.D. Rudnev, V.V. Bartold, B.Ya. Vdadimirtsov, G.Tsybikov, B.B. Baradin, Ts.Zh. Zhamtsarano. [3].

V. L. Kotvich, A. D. Rudnev, B. Ya. Vladimirtsov (1884-1931) taught at the Department of Mongolian and Kalmyk Literature of the Faculty of Oriental Languages

\footnotetext{
*Corresponding author: polgrab@ mail.ru

Corresponding author: ivansemushev@gmail.ru
} 
of St. Petersburg University, Vladislav Ludvigovich headed the department in 1899.

Mongol studies became the main component of V.L. Kotvich's scientific activity. He studied on the works of O.M. Kovalevsky (1801-1878) and taught at St. Petersburg University, using his Grammar and Anthology, and in many ways became a follower of his teacher. Since 1900, he became a private associate professor at St. Petersburg University and taught Mongolian and Manchurian languages until the reorganization of the Faculty of Oriental Languages of the University into the Faculty of Social Sciences (1919).

In 1900, after graduating from the university, A. D. Rudnev began teaching at his native department. A.D. Rudnev taught grammar of the written Mongolian language. He introduced new courses into the curriculum of students of Mongolian studies: "Samples of folk art", "Basics of spoken language", "Introduction to the study of Buryat dialects", "Experience of comparative review of Mongolian dialects", "Introduction to Mongolian studies" [4, 109]. Since 1909, B. Ya. Vladimirtsov started teaching. He proposed a new course "The Oirat (Kalmyk) language in ancient historical monuments and modern dialects". He lectured on the ethnography of the Mongolian peoples and conducted practical classes on the texts of the chronicle of Sagan-Setsen. The Mongolian scholars of St. Petersburg University worked closely with scientific societies.

At the beginning of the XX century, the first two associations of a special Oriental profile were created in Russia. The Imperial Society of Oriental Studies (1900) and the Russian Committee for the Study of Central and East Asia (1903). Mongolia and its neighboring regions occupied one of the most important places in the research of the Russian Committee. This was due to the numerous political processes taking place on its territories. Realizing that all the events of the beginning of the XX century could contribute to the loss of historical values, their loss for science, and at the same time, 1911 and 1912, associated with the acquisition of state sovereignty of the Khalkha, contributed to the work of Russian expeditions: Russia became a friendly state for independent Northern Mongolia, and these circumstances intensified expedition research. From 1908 to 1912 is the period of active work of the Mongolists of the Russian Committee V. Kotvich, A. Rudnev, B. Vladimirtsov. They fruitfully collaborated and directed the activities of Buryat researchers Tsyben Zhamtsarano and Bazar Baradiyn, who also became recognized specialists in Mongolian studies. Ts. Zhamtsarano and B. Baradiyn, with the support of the Committee, made repeated trips to the Trans-Baikal Buryats, as well as to Mongolia and Tibet. In 1910, B. Baradiyn continued to study the life of Buddhist monasteries in Transbaikalia, and Ts. Zhamtsarano continued to study folk literature from the Buryat-Khorin people. Thus, the Committee, through the organization of scientific trips, contributed to the training of orientalists.

The purpose of the Society of Oriental Studies was determined by the Charter: "mutual acquaintance of the peoples of Russia and the East with their material and spiritual life." To implement it, a number of departments were created in the Company: commercial, industrial, educational, scientific and cultural. In 1901, its regional branches were opened both in Central Asia and in the Russian Far East. The Society has become a center designed to solve pressing problems related to Russia's policy in these regions. In October 1909, the Practical Oriental Academy was established under him, which was headed by the Mongolian scholar Aleksey Matveyevich Pozdneev (after returning from Vladivostok, where he was the director of the Oriental Institute). The purpose of the return was to train personnel for service "in the eastern suburbs and neighboring countries". These trained specialists had to have a good command of Oriental languages and issues related to the current state of the states. Therefore, along with Chinese, Mongolian, Japanese, Persian, and Turkic languages, historical, economic, and political disciplines were included in the Academy's curriculum.

A. M. Pozdneev (since 1904 an official of the Ministry of Public Education) convinced the government to create a center for "practical Oriental studies" in St. Petersburg, along with the existing oriental institute in Vladivostok. In addition, A.M. Pozdneev is also the author of curricula for the Academy and manuals on the Mongolian language. He gathered a team of teachers for the students of this Academy. He lectured on the political situation in Mongolia at the beginning of the XX century. The diplomat and orientalist N.Ya. Korostovets and others A.M. Pozdneev emphasized that in Russia, which is so closely connected with the East by geographical and historical ties, there should be educational institutions of different levels: from schools of translators to institutes - universities that would train orientalists-practitioners at a high professional level.

However, for the most part, Orientalists opposed the training of Orientalists and Mongolian practitioners. They argued that it was possible to combine both theoretical and practical education in one university. About this "Note of a group of Russian Orientalists" about the project of the "Practical Oriental Academy", The authors of the note are leading orientalists of Russia at the beginning of the XX century -1920s: academicians V. V. Bartold, N. Ya. Marr, S. F. Oldenburg; Professors N. I. Veselovsky, A. I. Ivanov, F. I. Shcherbatskoy; privatdozents V. L. Kotvich, I. Y. Krachkovsky, A.D. Rudnev sharply criticized the project. Scientists wrote: "The drafters of the project are convinced of the incompatibility of the "theoretical school of Oriental studies" with the "practical school of language". We can agree with this, since we are talking about assigning narrow-practical (in public life, narrow-departmental) tasks to the scientific school and striving to achieve practical results faster to the detriment of theoretical training. Otherwise, the distance between science and life does not increase with the development of culture, but decreases. Scientists - historians and archaeologists know that in order to understand the country's past, it is necessary to get acquainted with its modern life. It is also known that when solving practical issues, the one who speaks fully armed with knowledge has the 
advantage» [5, 78]. It's hard to argue with such arguments. However, as the history of the development of Oriental studies shows, St. Petersburg University did not pay much attention to the modernity of the Eastern peoples. However, the reality of the international situation required highly qualified specialists who knew both the language and the most up-to-date information for solving state tasks. What the Oriental Institute in Vladivostok was focused on.

The Oriental Institute (1899) was a completely new institution, not only in terms of the time of its opening, but also in terms of teaching methods, both languages and all other courses of Oriental studies. All the courses studied were only practical in nature, whereas in Russian science the scientific and theoretical study of the East dominated. The Institute quickly became the best school in Russia, the so-called practical Oriental studies [6], and A.M. Pozdneev is called the founder of the "scientific formulation of the study of modern Mongolia" [7].

A. M. Pozdneev, well aware of the situation in the countries of the Far East, insisted that the system of organizing Oriental education in Russia should be flexible, most adapted to the requirements of real time. Therefore, he arranged the training of students at the VI according to the needs of the state in practitioners [6].

Having created the Oriental Institute in Vladivostok for practical orientalists, he prepared a generation of Mongolian practitioners. Later, A.M. Pozdneev, already working in the Ministry of Education, carried out work on expanding the number of educational institutions with a practical Oriental bias, made inspection trips to schools of Oriental languages, was engaged in improving the quality of training of Orientalists. The main task he was engaged in was the publication of textbooks for schools where the Mongolian language was taught.

Irkutsk University, which opened in 1918, became another center of Mongolian studies in the Russian Far East. A number of circumstances contributed to this.

Firstly, the city was a place with a rich tradition of studying the Mongolian language and the history of Mongolia.

Secondly, there were Comintern organizations in Irkutsk in 1918-1921; they provided assistance to the Mongolian revolutionaries.

Thirdly, in the 20s in Irkutsk, as a result of the events of the revolution and the Civil war, there were many orientalists from Moscow, Petrograd, Orenburg, who intensified the study of Mongolia. B. E. Petri, G. S. Vinogradov, M. K. Azadovsky, Ts.Zhamtsarano, G. Tsybikov, V. A. Ryazanovsky, S. V. Shostakovich, N. N. Kozmin worked here.

And fourthly, in 1926-1932 Irkutsk University has started training Mongolian students and training specialists for the party and state organizations of the MPR. It also increased interest in the country, its history and language [8]. Mongolian studies at Irkutsk University held leading positions. The Mongolian language was taught by Ts. Zh. Zhamtsarano [9], educated at St. Petersburg University, S. P. Kuznetsov, who graduated from the Oriental Institute in Vladivostok, etc. All this speaks about the continuity of generations of Mongol scholars, their belonging to the same school - the Russian one, represented by different centers at the beginning of the XX century. The activity of training Mongolian specialists was determined either by the tasks of classical Oriental studies, or practical the study of the modern East. In the pre-revolutionary period, the first direction dominated in Russian Oriental studies, and during the formation of Soviet science, the second became a priority. In this connection, it is possible to disagree with the existing opinion [5, 42] which asserts that the study of problems related to the current situation of the East in pre-revolutionary Oriental studies has not developed. Despite the radical transformations that took place in Oriental studies with the establishment of Soviet power, Soviet Mongolian studies were formed under the influence of prerevolutionary Russian Mongolian studies, its practical direction, updated by A.M. Pozdneev.

1917-1922 was the time when the basic principles of the Soviet higher school, the organization of research work, as well as science, the structures of new state institutions designed to plan and regulate scientific and educational pedagogical activities in the country, the training of Oriental specialists were formed. The reorganization of existing universities and the creation of new ones has begun. The Lazarev Institute of Oriental Languages in Moscow was one of the first to undergo a radical restructuring. According to its profile, the Institute was Middle Eastern [10]. At that time, the capital did not have any departments or faculty that would study the countries of the Far East, Southeast Asia, even India (except for Indian philology). It is amazing that in a short time, in just two or three years, it was possible to make Moscow one of the centers for training specialists in the Far East and India [5, 52]. March 4, 1919 by decree of the Council of People's Commissars of the RSFSR, signed by V. I. Lenin, the Armenian Institute was created instead of the Lazarev Institute of Oriental Languages. The document determined the need to study the socio-economic development of the countries of the East, classes, the alignment of class forces, the nature and prospects of the national liberation movement, the study of living languages. In fact, the direction of development of all possible future higher educational institutions was determined. The creation of the Central Oriental Institute was actively discussed both in Moscow and Petrograd. The decision of the Presidium of the Central Bureau under the Central Committee of the Russian Communist Party of the Bolsheviks of August 25, 1925 on the Central Oriental Institute: "... to demand from the People's Commissariat of the organization of the Institute in Moscow, having disbanded the former Lazarev Institute and to pour into it the Oriental Faculty of Petrograd University." In 1920, the chairman of the Council of People's Commissars V. I. Lenin signs the "decree on the establishment of the Central Institute of Living Oriental Languages" in Moscow. In addition to this institute, the Petrograd Institute of Living Oriental Languages was founded at the same time $[5,55]$. The purpose of the Institute is to enable persons preparing for practical activities in the East or in connection with the East in any field (economic, administrative-political, 
agitation, diplomatic, pedagogical, etc.) to acquire the necessary Oriental knowledge and pass a systematic school of practical Oriental studies. In addition, to train teachers and qualified instructors for practical courses in Oriental studies. Thus, the tradition of practical Oriental studies education in Russia continues to develop actively. This was not the end of the reorganization of Oriental universities. There was a question of creating such an educational institution where, along with living languages, regional studies disciplines would come out on top. In October 1921 the Presidium of the All-Russian Central Executive Committee adopted a resolution on the merger of the University and the Eastern Branch of the University into one higher educational institution the Institute of Oriental Studies.

In 1922, the question arose about the merger of the Petrograd Institute of Living Oriental Languages with the Moscow Institute. The association was opposed by the teachers of the Institute of Oriental Studies, they were supported by the College of Orientalists at the Asian Museum, arguing that the refusal was inexpedient, "there will be no savings from the merger," which they tried to achieve due to lack of funds to maintain two centers of Oriental studies. And this time the merger was avoided.

\section{Conclusion}

Academician A. N. Kononov, assessing the results of the activities of two Petrograd educational centers of Oriental education, wrote that Oriental studies at the Faculty of Social Sciences of the First Petrograd University, «having turned into only one of the specializations of this huge humanitarian combine, is slowly fading; the center for training orientalists is turning into the Petrograd Institute of Living Oriental Languages. In which the teaching was conducted by the best forces of Petrograd Oriental studies» [5, 58-59]. In fact, the situation that developed at the turn of the XIXearly XX centuries was repeated. Some fading of the role of St. Petersburg University as a classical center of Oriental studies, against the background of a powerful impulse of the formation of the Oriental Institute in Vladivostok, and then the Practical Oriental Academy at the Society of Oriental Studies in St. Petersburg, the demand for orientalists-practitioners who know the East well. The accumulated experience of training practical orientalist personnel in pre-revolutionary St. Petersburg became the starting point for the reorganization and creation of new educational institutions. There was no question of an acute shortage of textbooks or teaching staff, which cannot be said about Moscow. Many St. Petersburg orientalists had to come to Moscow to conduct classes at the Central Institute of Living Oriental Languages. And a number of areas of Oriental studies, especially the training of specialists in the Far East, had to be created from scratch. But we must pay tribute, in a very short period of time, Moscow is becoming the main training center for the modern East. The division of Oriental studies into classical and practical that emerged in pre-revolutionary Russia was continued in the Soviet period, with centers in Moscow and Leningrad, practical and classical, respectively. The training of Mongol scholars in the 1920s was carried out mainly in Leningrad and Irkutsk. At the same time, there was a process of creating new research centers and associations, as well as educational institutions. It is fundamentally important that new Oriental studies institutions have emerged in Tashkent, Baku, Tbilisi, Yerevan, Kazan, Ufa, Verkhneudinsk (since 1934 UlanUde).

The work was supported by the RFBR grant (project No. 20-59-44008 "World and Russian Mongolian studies: national schools, concepts, personalities").

\section{References}

1. Istoriya otechestvennogo vostokovedeniya do serediny XIX v. (1990) [The history of Russian Oriental studies until the middle of the XIX century].

2. O. N. Polyanskaya, Mongolovednye issledovaniya V.L. Kotvicha (1872-1944). K 140-letiyu so dnya rozhdeniya,Vestnik Buryatskogo gosuniversiteta 7, 108-114 (2012). [Mongolian studies by V.L. Kotvich (1872-1944). To the 140th anniversary of his birth.]

3. A. M. Kulikova, Vostokovedenie $v$ rossiiskikh zakonodatel'nykh aktakh (konets XVII-1917 g.), Tsentr «Peterburgskoe vostokovedenie» (1993) [Oriental Studies in Russian Legislative Acts (late XVII-1917)].

4. D. B. Ulymzhiev, Mongolovedenie $v$ Rossii vo vtoroi polovine XIX - nachale XX vv.: Peterburgskaya shkola mongolovedov (1997) [Mongol studies in Russia in the second half of the XIX - early XX centuries: St. Petersburg School of Mongol Studies].

5. A. P. Baziyants. Iz istorii sovetskogo vostokovedeniya, Stanovlenie sovetskogo vostokovedeniya. Sbornik statei, Nauka (1983) [From the history of Soviet Oriental Studies].

6. O. N. Polyanskaya, Mongolovedenie $v$ universitetakh Rossii $v$ XIX - nachale XX vv. Vostochnyi institut vo Vladivostoke. Gumanitarnyi vektor 3 (27), 48-53 (2011) [Mongolian studies at Russian universities in the XIX - early XX centuries . Oriental Institute in Vladivostok.].

7. V. M. Alekseev, Nauka o Vostoke. Stat'i $i$ dokumenty, Glav. red. vost. lit., (1982) [The science of the East. Articles and documents].

8. Yu. V. Kuz'min, V. V. Svinin, Irkutskaya shkola mongolovedeniya (XVIII-XX vv.), Izd. BGUEHP (2014) [Irkutsk School of Mongolian Studies (XVIII-XX centuries)].

9. YA. V. Vasil'kova, M. YU. Sorokinoi, Lyudi $i$ sud'by. Biobibliograficheskii slovar' vostokovedov zhertv politicheskogo terrora $v$ sovetskii period (1917-1991), Peter. vost., (2003) [People and destinies. Biobibliographical Dictionary of Orientalists - victims of Political terror in the Soviet Period (1917-1991)]. 
10. A. V. Torkunov, Lazarevskii institut vostochnykh yazykov $v$ kontekste istorii vostokovedeniy, Polis. Politicheskie issledovaniya 6, 9-22 (2015) [Lazarev Institute of Oriental Languages in the context of the History of Oriental Studies]. 